\title{
НОВІ МОДЕЛІ СЕНСОРІВ ТЕПЛОВОГО ПОТОКУ ДЛЯ СИСТЕМ МОНІТОРИНГУ ТА ДІАГНОСТИКИ ЕНЕРГЕТИЧНОГО ОБЛАДНАННЯ
}

\author{
Воробйов Л.Й., канд. техн. наук, Декуша Л.В., докт. техн. наук, Ковтун С.І., канд. техн. наук
} Інститут технічної теплофізики НАН Украӥни, вул. Желябова, 2а, Київ, 03680, Україна

В роботі розглянуто принципи побудови сенсорів теплового потоку для застосування в системах моніторингу об'єктів теплоенергетики в залежності від умов теплообміну та характеристик об'єкта контролю, зокрема, сенсорів зі зменшеним тепловим опором, застосування яких дозволяе вимірювати густину теплового потоку в умовах високоінтенсивного теплообміну; сенсорів спеціального призначення для дослідження неусталених процесів теплообміну, тощо.
В работе рассмотрены принципы построения сенсоров теплового потока для применения в системах мониторинга объектов теплоэнергетики в зависимости от условий теплообмена и характеристик объекта контроля, в частности, сенсоров с уменьшенным тепловым сопротивлением, применение которых позволяет измерять плотность теплового потока в условиях высокоинтенсивного теплообмена; сенсоров специального назначения для исследования неустановившихся процессов теплообмена, и тому подобное.
The paper discusses the construction principles of heat flow sensors for use in monitoring systems of thermal power equipment, taking into account the depending on the heat transfer conditions and the characteristics of the control object. In particular, considers the sensors with a reduced thermal resistance, the use of which allows to measure the heat flux in the conditions of high heat transferring; special sensors for research of transient heat transfer, and so on.

Бібл. 14, рис. 9.

Ключові слова: сенсори теплового потоку, системи моніторингу, енергетичне обладнання.

Для моніторингу та діагностування об’єктів теплоенергетики при виробництві і транспортуванні теплоти, зокрема, для дослідження процесів спалювання палива в топках котлоагрегатів, тепловтрат при транспортуванні теплоносія по трубопроводах, процесів теплообміну крізь огороджувальні конструкції енергетичного устаткування, тощо, інформативними $є$ методи теплометрії та теплометричні прилади і системи, побудовані на базі перетворювачів (сенсорів) теплового потоку. Для вдосконалення метрологічних та експлуатаційних характеристик сенсорів в залежності від умов їх застосування в системах моніторингу та діагностики енергетичного обладнання проведено низку досліджень та розробок.

\section{Сенсори теплового потоку з тепловими шунтами.}

При вимірюванні теплового потоку в умовах конвективного i конвективно-радіаційного теплообміну на величину методичної похибки впливає власний тепловий опір сенсорів, який при використанні традиційних електроізоляційних компаундів 3 теплопровідністю $(0,2 \ldots 1,2) \mathrm{BT} /(\mathrm{M} \cdot \mathrm{K})$ може змінюватися в межах від $5 \cdot 10^{-4} \mathrm{M}^{2} \cdot \mathrm{K} / \mathrm{BT}$ до $10^{-2} \mathrm{M}^{2} \cdot \mathrm{K} / \mathrm{BT}$. Зменшення теплового опору сенсорів для коректного їх застосування в зазначених умовах досягнуто введенням в конструкцію теплових шунтів.

Можливі конструктивні рішення сенсорів 3 тепловими шунтами i температуровирівнювальними покриттями показані на рисунку 1 при виконанні сенсорів у металевому корпусі і на рисунку 2 - схема побудови сенсорів 3 дротовим тепловим шунтом $[1,2]$.

Однією 3 перших моделей сенсорів 3 тепловим шунтом, застосованих в приладах для дослідження теплофізичних властивостей матеріалів, характеристик теплових труб та інших об'єктів, з'явилася конструкція сенсору 3 фрезерованим металевим корпусом, показана на рисунку $1, a$. Такий сенсор складається з корпусу, в паралельних пазах якого розміщена стрічкова термобатарея, залита електроізоляційним компа- 
ундом. Після полімеризації компаунда до корпусу припаяна кришка. Через отвори в бічній поверхні корпусу виведені потенціалоз'ємні дроти термобатареї. Недоліком такої конструкції $є$ те, що термоелементи і заливний компаунд під час пай-

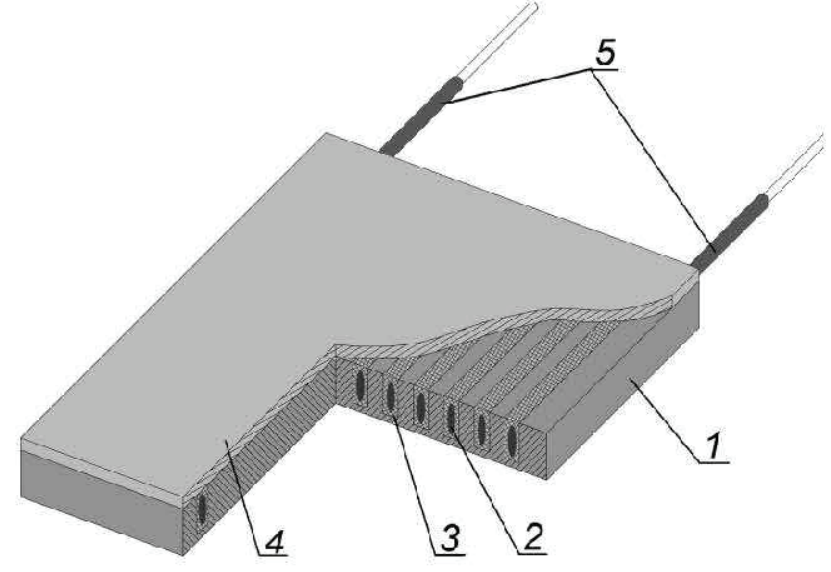

$\boldsymbol{a}$ - периа модель

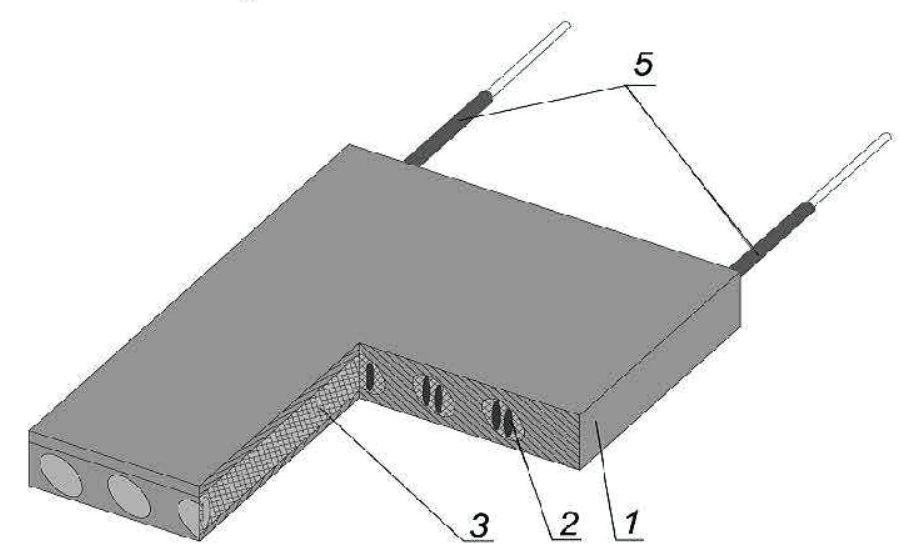

6- третл модель ки кришки до корпусу зазнають впливу високої температури, що висуває жорсткі технологічні вимоги до властивостей заливного компаунда і гальванічного покриття.

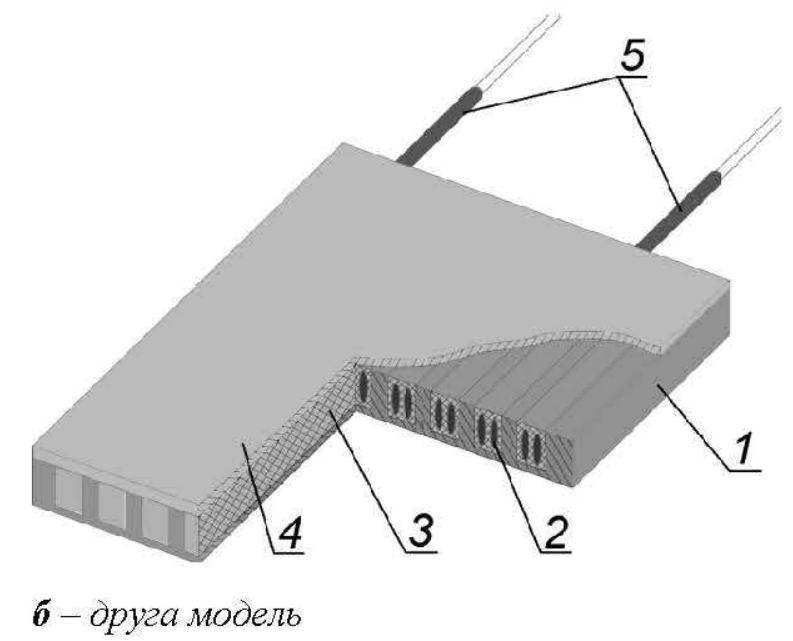

1 -металевий корпус;

2-стрічкова батарея термоелементів;

3 - електроізолячійний заливний компаунд;

4-кримка;

5- потенуіалоз' ємні дроти

\section{Рис. 1. Варіанти моделей сенсорів з тепловими шунтами, щзо виготовлені в металевому корnyci.}

Від цього недоліку позбавлена друга модель сенсору (див. рис. 1, б), технологія виготовлення якої передбачає припаювання кришки до корпусу відразу після фрезерування пазів. При цьому пази виконують більшої ширини (не менше ніж в 2 рази) і в них вкладають складену вдвічі стрічкову спіраль, попередньо оповиту ниткою, просочену заливальним компаундом. Надлишки компаунда видаляються через відкриті торці пазів корпусу.

При необхідності розміщення сенсора на досліджуваній поверхні 3 високою температурою надійний тепловий контакт забезпечують зазвичай із застосуванням легкоплавкого при- пою або галій-індієвої евтектики. Але при цьому $\epsilon$ небезпека потрапляння цих речовин на паяні шви корпусу і взаємодії їх з припоєм. В такому разі доцільно сенсор виготовляти в суцільному металевому корпусі у вигляді пластини, в якій висвердлені отвори для розміщення стрічкової батареї (див. рис. 1, в).

У моделі сенсора, представленій на рис. 2, стрічкова термобатарея 3 нанесеним гальванічним покриттям додатково обвивається електроізольованим дротом, мідним або константановим, діаметр і щільність навивки якого вибирають, виходячи 3 розрахунку необхідного 
значення ефективного теплового опору сенсо- розміщеного паралельно за тепловим потоком до ра. Цей дріт виконує функцію теплового шунта, термоелементів.

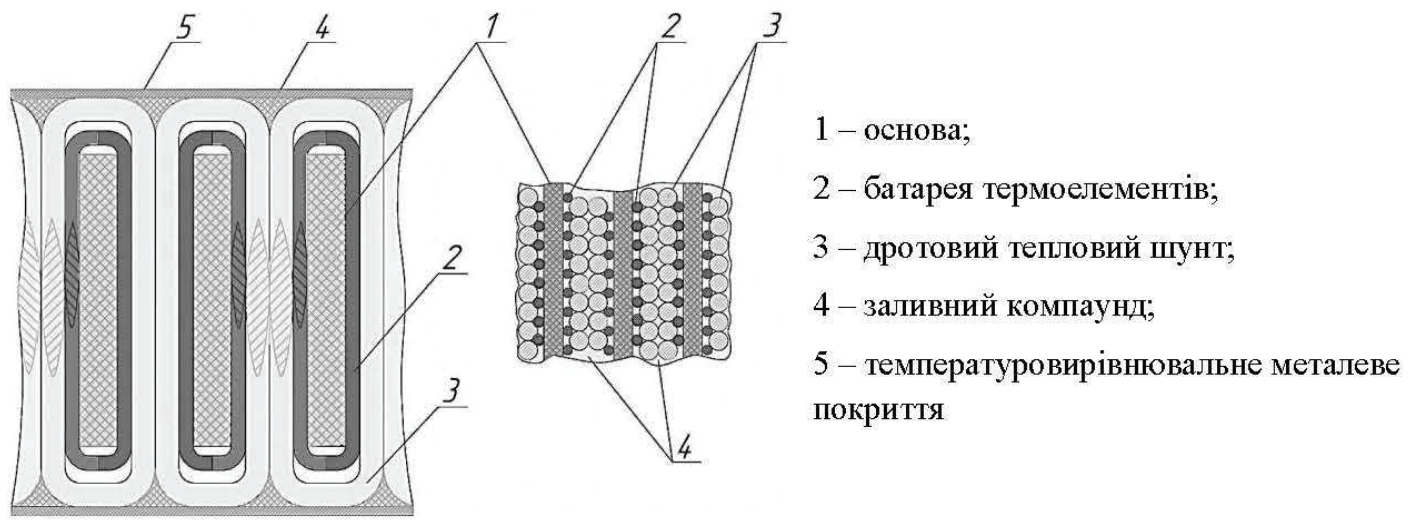

\section{Рис. 2. Схема побудови сенсора з дротовим тепловим иунтом.}

Подальша технологія виготовлення сенсора не відрізняється від традиційної, неодноразово описаної в літературі [3-5].

Після отримання заготовки сенсору типу допоміжної стінки, що складається з гальванічних термоелементів, заформованими разом 3 дротяними шунтами в заливальному компаунді, робочі поверхні сенсора шліфують до появи в зрізі перетинів шунтувального дроту i, при необхідності, металізують, утворюючи тим самим температуровирівнювальні покриття поверхонь сенсора, що сприймають і віддають теплоту.
Це дає можливість змінювати ефективний тепловий опір сенсора в широкому діапазоні значень, а наявність температуровирівнювального покриття обох поверхонь з шунтами забезпечує рівномірність поля теплового потоку на вході і виході з сенсора.

Як показано в роботі [1], тепловий опір ПТП 3 шунтами дорівнює напівсумі опорів, знайдених за ізотермічною та адіабатною моделями дроблення елементарної комірки:

$$
R_{\text {ПтाП }}=0,5 \cdot\left(R_{I 3}^{Ш}+R_{A Д}^{Ш}\right) .
$$

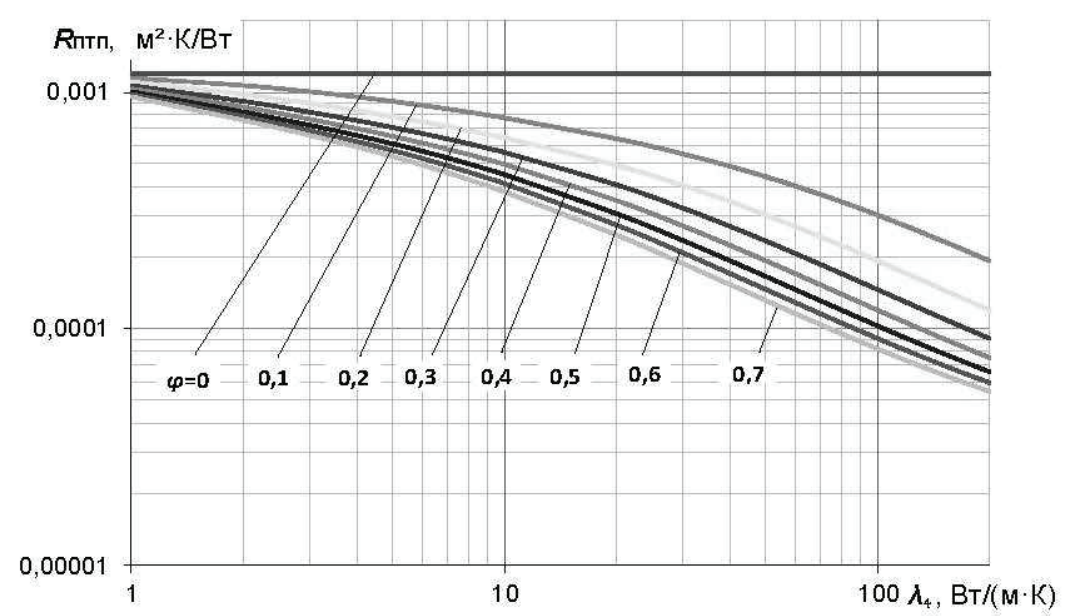

\section{Рис. 3. Залежність ефективного теплового опору сенсора теплового потоку від теплопровідності иунта при варіації геометричного параметра иунта $\varphi$.}

На рисунку 3 наведено результати теоретичного дослідження залежності ефективного теплового опору сенсора від теплопровідності шунта при варіації геометричного параметра шунта $\varphi=f_{4}\left(2 f_{1}+f_{2}+f_{3}+f_{4}\right)$, де $f_{i}-$ площа перерізу компонентів одиничного термоелемента згідно 
3 індексом ( $i=1$ - основний термоелектрод; 2 гальванічне покриття; 3 - заливний компаунд; 4 - тепловий шунт). Використання теплових шунтів дозволило знизити власний тепловий опір сенсорів більш ніж на порядок і наблизити ефективну теплопровідність сенсорів до теплопровідності металів.

Таким чином, завдання щодо забезпечення вимірювання густини теплового потоку 3 більшою точністю на конкретному об'єкті iз застосуванням сенсору теплового потоку, який має необхідне для узгодженості 3 теплофізичними характеристиками об'єкта значення ефективного теплового опоpy, вирішується введенням в конструкцію теплового шунта з відповідними геометричним параметром і коефіцієнтом теплопровідності.

\section{Біспіральні сенсори теплового потоку.}

Практика багаторічної експлуатації термоелектричних біметалевих багатоелементних сенсорів теплового потоку розкрила їх недоліки, основними 3 яких $€$ значні обмеження діапазону температури при експлуатації і залежність функції перетворення від температури.

Стабільність у часі характеристик сенсора, зокрема метрологічних, залежить від безлічі факторів, деякі з них подібні тим, що впливають на термоелектричні перетворювачі температури (термопари), але існує i ряд факторів специфічних для сенсорів теплового потоку. В процесі експлуатації сенсори піддаються фізичному старінню, в результаті чого змінюються властивості термоелементів. Основні причини цих змін - окислення і дифузія металів термоелектродів, зміна структури металів i заливного компаунда, дифузія домішок і забруднення металів.

Проблема, пов'язана 3 часовою стабільністю метрологічних характеристик сенсорів, вирішена шляхом переходу від широко використовуваних мідних покриттів i покриттів 3 дорогоцінних металів до нікелевих покриттів.

Завдяки високій корозійній стійкості нікелю та його більшому питомому опору отримані пари копель-нікель i константан-нікель, що відрізняються високою стабільністю в часі навіть в умовах експлуатації сенсорів за температури до 500 К. Причому, в діапазоні температури від 300 К до 500 К зміна функції перетворення таких сенсорів не перевищує $3 \%$.

Подальше підвищення температури призводить до істотної зміни функції перетворення i появи піків при температурі точки Кюрі для нікелю.

Цей недолік усунуто створенням біспіральних сенсорів, що сконструйовані з двох термобатарей $[6,7]$. Причому, обидві термобатареї виконуються 3 нікелевим покриттям, а основою додаткової термобатареї є парний термоелектрод (рис. 4, a i б).

Сумарна чутливість двох термобатарей, включених послідовно за електричним сигналом та паралельно тепловому потоку, розраховується за формулою:

$S_{\Sigma}=\alpha_{1}^{3} \cdot z_{1} /\left[1+\left(\rho_{3} \cdot f_{1}\right) /\left(\rho_{1} \cdot f_{31}\right)\right]-\alpha_{2}^{3} \cdot z_{2} /\left[1+\left(\rho_{3} \cdot f_{2}\right) /\left(\rho_{2} \cdot f_{32}\right)\right]-$

$-\alpha_{3}^{\prime} \cdot\left(z_{1} /\left[1+\left(\rho_{3} \cdot f_{1}\right) /\left(\rho_{1} \cdot f_{31}\right)\right]-z_{2} /\left[1+\left(\rho_{3} \cdot f_{2}\right) /\left(\rho_{2} \cdot f_{32}\right)\right]\right)$,

де $\alpha_{1}^{3}, \alpha_{2}^{3}, \alpha_{3}^{3}$ - коефіцієнт Зеєбека матеріалів основних дротів 1 і 2 та матеріалу покриття $3 ; z_{1}$, $z_{2}-$ кількість термоелементів в першій та другій термобатареях відповідно; $\rho_{1}, \rho_{2}, \rho_{3}-$ питомий електричний опір основних дротів 1,2 та покритТя 3.

Якщо підібрати пару термоелектродних дротів таким чином, аби виконувалася рівність $z_{1} /\left(1+\rho_{3} \cdot f_{1} / \rho_{1} \cdot f_{31}\right)=z_{2} /\left(1+\rho_{3} \cdot f_{2} / \rho_{2} \cdot f_{32}\right), \quad$ то чутливість сенсора не залежатиме від властивостей матеріалу покриття і розраховується за формулою:

$S_{\Sigma, \text { opt }}=\alpha_{1}^{3} \cdot z_{1} /\left(1+\rho_{3} \cdot f_{1} / \rho_{1} \cdot f_{31}\right)-\alpha_{2}^{3} \cdot z_{2} /\left(1+\rho_{3} \cdot f_{2} / \rho_{2} \cdot f_{32}\right)$.

При виготовленні біспірального сенсора можливі кілька конструктивних рішень, які схематично показані на рисунку $5, a$ і $\sigma$, коли спіраль поставлена на «ребро» і на рисунку 6, коли спіраль розташована «плазом».

За першим варіантом конструкції на рис. 5, а обидві спіралі 3 основних термоелектродних дротів 1 і 2 з електролітичними покриттями 3.1 i 3.2 напіввитків навито на окремі каркасні стрічки 4 i 5. Ці стрічки виконані зі смужок електроізоляційного матеріалу однакової висоти і розташовані паралельно, так, що верхні спаї обох спіралей знаходяться в одній площині, а нижні спаї - в інший. Площини спаїв паралельні і рознесені на висоту термобатареї. Обидві спіралі 
з'єднані послідовно у спаї 6 і зафіксовані у вигляді пластини електроізоляційним компаундним матеріалом (на рис. 5 не показаний). Сигнал біспірального сенсора знімається за допомогою потенціалоз'ємних дротів 7.

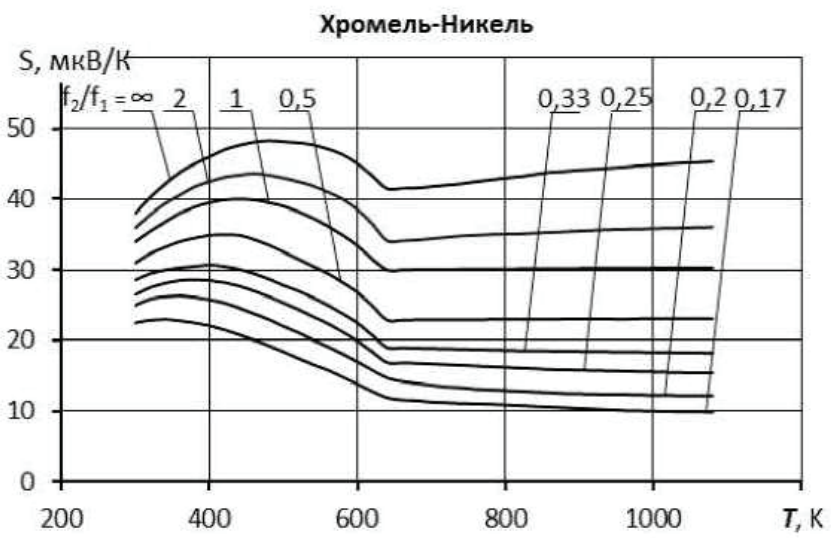

б)

Рис. 4. Температурні залежності чутливості термоелементів, включених послідовно за електричним сигналом.

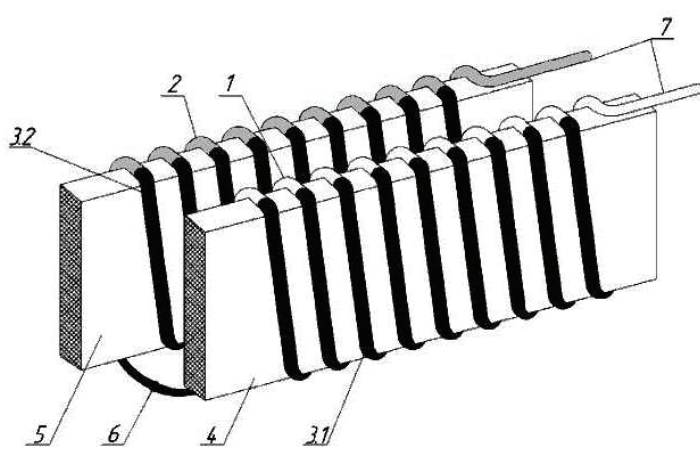

a)

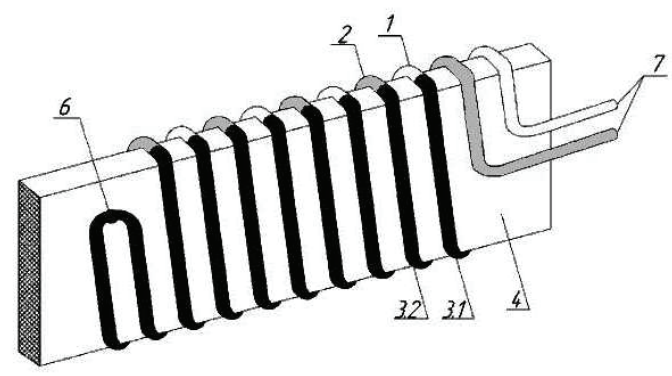

б)

Рис. 5. Варіанти виконання батареї термоелементів біспірального сенсору теплового потоку (спіраль поставлена на «ребро»):

1 - основний термоелектродний дріт периої спіралі; 2 - термоелектродний дріт другої спіралі; 3.1, 3.2 - електролітичне покриття відповіднх напіввитків кожної спіралі;

4, 5 - каркасні ізоляційні стрічки; 6-спай з'єднання спіралей;

7 - потенціалоз'ємні дроти батарей термоелементів. 
Конструкція сенсора за другим варіантом (див. рис. 5, б) відрізняється тим, що обидві спіралі розташовані на загальній каркасній стрічці 4, при цьому термоелектродні дроти 1 i 2 навито один відносно іншого зі зміщенням на ізолюючий проміжок, який не допускає електричного контакту між термоелементами.

Конструкція сенсорів 3 розташуванням

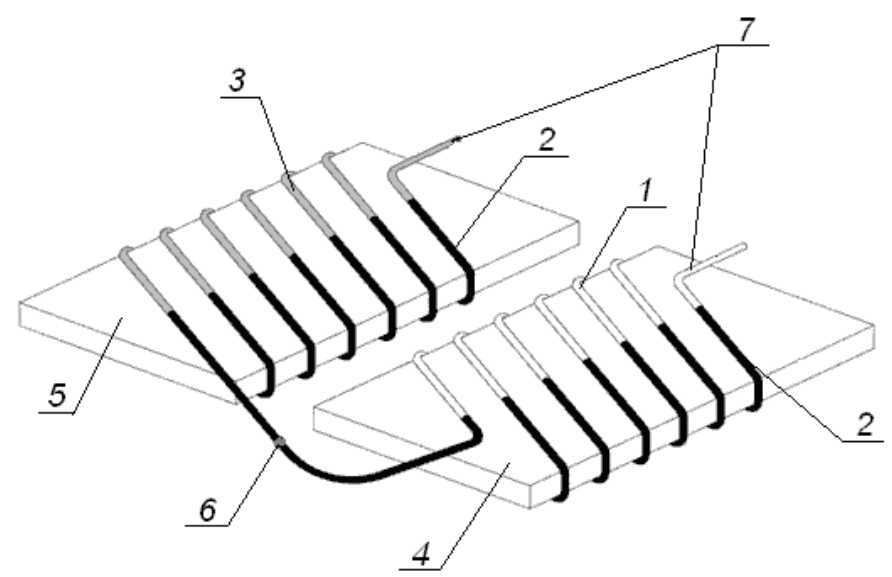

a) спіралі «плазом», представлена на рис. 6, також може бути виконана в двох варіантах, аналогічних вже описаним, тобто 3 двох спіралей на індивідуальній стрічці-носієві кожна (варіант а) і на спільній стрічці (варіант б), але зі зміщенням на проміжок для виключення торкання витків однієї спіралі з витками іншої спіралі.

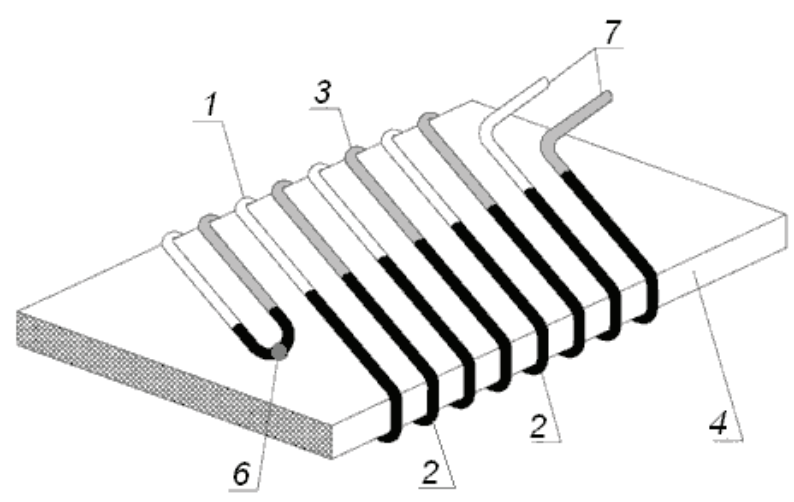

б)

Рис. 6. Варіанти виконання батареї термоелементів біспірального сенсору теплового потоку (спіраль розташована «плазом»):

1 -основний термоелектродний дріт периої спіралі; 2 - термоелектродний дріт другої спіралі;

3 -електролітичне покриття напіввитків кожсної спіралі; 4, 5-каркасні ізоляційні стрічки; 6 - спай з'єднання спіралей; 7 - потенціалоз'ємні дроти батарей термоелементів.

\section{Сенсори теплового потоку з поліметалічним покриттям.}

Підвищити чутливість біметалевих сенсорів вдалося шляхом нанесення на обидва напіввитки дроту-основи батарей сенсора гальванічного покриття $з$ парних термоелектродних матеріалів, що мають високі значення коефіцієнта Зеєбека $\alpha^{3}$, але які не випускаються у вигляді дроту (наприклад, сурма, вісмут).

Для розрахунку оптимальних значень чутливості сенсора й необхідної для цього товщини покриттів розглянута еквівалентна електричного схема термоелемента, наведена на рис. 7, де індекс «1» відповідає основному термоелектроду, «2» $\mathrm{i} « 3 »-$ двом гальванічним покриттям.

За наявності різниці температури $\Delta T$ між вузлами контуру виникають струми $I_{1}, I_{2}, I_{3}, I_{4}$, а між вузлами В і С виникає різниця потенціалів $\Delta U$, яка згідно з правилом Кірхгофа для ланцюгів постійного струму розрахована за формулою:

$$
\Delta U_{C B}=\left(\frac{\alpha_{3}^{3}-\alpha_{1}^{3}}{R_{1}+R_{3}}+\frac{\alpha_{1}^{3}-\alpha_{2}^{3}}{R_{1}+R_{2}}\right) \cdot R_{1} \cdot \Delta T,
$$

3 урахуванням формули (4) розрахункове співвідношення для приведеної чутливості $S_{V}=S \cdot(A \cdot h)^{-1}$ біметалевих сенсорів набуває вигляду:

$$
S_{V}=\frac{1}{\lambda_{1} \cdot f_{1}} \cdot \frac{\alpha_{3}^{3} /\left(1+\rho_{31} / f_{31}\right)-\alpha_{2}^{3} /\left(1+\rho_{21} / f_{21}\right)+\alpha_{1}^{3} /\left(\left(1+\rho_{21} / f_{21}\right)^{-1}-\left(1+\rho_{31} / f_{31}\right)^{-1}\right)}{2+\lambda_{21} \cdot f_{21}+\lambda_{31} \cdot f_{31}+\lambda_{41} \cdot f_{41}},
$$

де $\rho_{i 1}=\rho_{i} / \rho 1-$ приведений питомий електричний опір; $f_{i 1}=f_{i} / f_{1}-$ приведена площа перерізу; $\lambda_{i 1}=\lambda_{i} / \lambda_{1}-$ відношення коефіцієнтів теплопровідності (індексами позначені: $i=1$ дріт ос- 
нова, $i=2 ; 3$ гальванічне покриття, $i=4$ заливний компаунд).

При $\rho_{21} / f_{21}=\rho_{31} / f_{31}$ чутливість сенсора не залежить від матеріалу основного термоелектроду термобатареї та визначається тільки коефіцієнтами Зеєбека матеріалів покриття.

Таким чином, використання поліметалічних термоелектродів при виготовленні сенсорів теплового потоку дозволяє захищати термоелемен- ти від корозії і використовувати термоелектродні матеріали, що мають більш високе значення коефіцієнта Зеєбека в порівнянні $з$ традиційними парами, але не випускаються у вигляді дроту. Це відкриває шлях до підвищення стабільності характеристик сенсора, а також збільшення його чутливості при одночасному зменшенні електричного опору $[8,9]$.

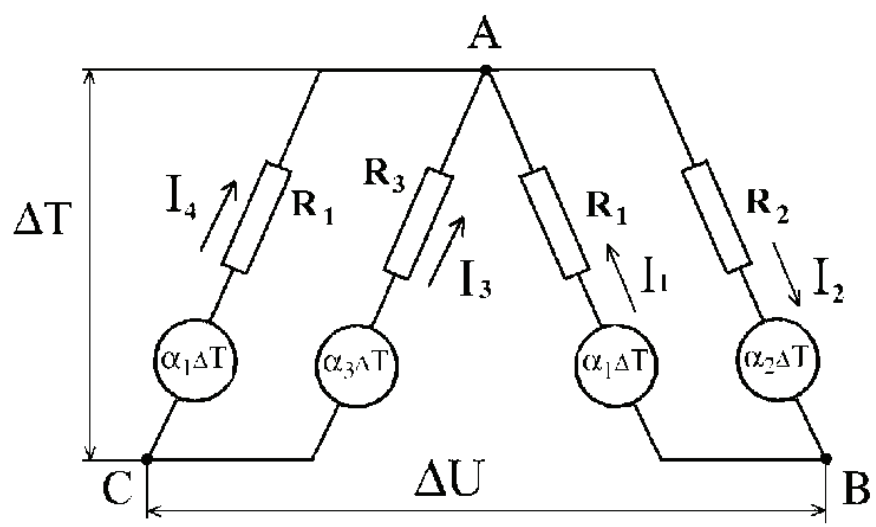

Рис. 7. Еквівалентна електрична схема термоелемента з иарами термоелектричних покриттів на напіввитках.

\section{Сенсори теплового потоку для дослідження нестаціонарних теплових процесів.}

Прогрес науки і техніки, а також актуальність вирішення злободенних задач в області енергетики і будівельної індустрії вимагають безперервного вдосконалення вимірювальних систем для збору інформації про режими роботи устаткування, їх стан і енергетичні втрати.

Наприклад, при натурному теплотехнічному обстеженні стану теплозахисту споруджуваних і поставлених на ремонт будівель споруди $60 \ldots 80$ років $\mathrm{XX}$ століття з'явилася проблема, пов'язана зі збільшенням методичної похибки вимірювання теплового потоку, який, 3 одного боку, має малу густину (від $3 \mathrm{BT} / \mathrm{M}^{2}$ до $10 \mathrm{BT} / \mathrm{M}^{2}$ ), 3 іншого - постійно змінюється. Для енергетичного обладнання, в свою чергу, характерні, як правило, високі значення температури і густини теплового потоку і динамічні теплові режими.

Ці обставини потребують створення первинних вимірювальних перетворювачів і вимірювальної системи, що здатна давати адекватну інформацію про параметри швидкоплинних теп- лових процесів в умовах постійно мінливої температури поверхні об'єкту контролю.

Сенсори кінцевої товщини, що мають індивідуальну статичну функцію перетворення, призначені тільки для вимірювання стаціонарного або повільно змінного теплового потоку. Швидкодію або інерційність сенсорів характеризують часом реакції та постійною часу [5]. Час реакції сенсора теплового потоку визначають як час з початку впливу теплової енергії до моменту досягнення вихідним сигналом деякого заданого рівня від сталого значення, наприклад, 0,99. Постійна часу характеризує швидкодію сенсора вельми умовно, адже нестаціонарні процеси в сенсорі описуються, як правило, значно складніше, ніж проста експоненціальна зміна у часі. Час реакції за рівнем 0,99 (час встановлення показань) для сенсора 3 експоненційною перехідною характеристикою пов'язаний 3 постійною часу в такий спосіб: $t_{0,99} \approx 5 \cdot \tau_{0,63}$. Таким чином, для дослідження нестаціонарних теплових процесів постійна часу сенсора повинна бути в $(5 \ldots 10)$ разів менше, ніж характерний час зміни теплової дії. 
Якщо для вимірювання стаціонарного теплового потоку за допомогою сенсора виду допоміжної стінки достатньо визначити різницю температури на торцевих поверхнях термобатареї, тобто виконати диференціювання між двома його перерізами, то в разі вимірювання нестаціонарних процесів кількість перерізів, між якими виконується диференціювання, має бути збільшена. Це дозволяє на порядок зменшити інтервал часу реакції сенсора на зовнішню теплову дію. На практиці для збільшення кількості перерізів у конструкцію сенсора вводять додаткову корегувальну термобатарею, в якій площини розміщення спаїв не співпадають 3 площинами спаїв основної термобатареї [10-14].

В результаті математичного моделювання встановлено, що для збільшення швидкодії сенсора теплового потоку необхідно підсумовувати в певній пропорції сигнали, що відповідають різниці температури в шарах пластини сенсоpa [10]. У загальному випадку співвідношення сигналів може бути різним. Сигнал, що формується за допомогою термобатарей, спаї яких розташовані в перерізах з координат $\eta$ і (1$\eta)$, та відповідає зміні в часі виміряного значення густини теплового потоку $q(\tau)$ відносно густини теплового потоку $q_{0}$, який надходить на теплосприймальну поверхню сенсора, визначається як: $\frac{q(\tau)}{q_{0}}=\frac{\lambda}{h \cdot \eta}\{[\theta(0, \tau)-\theta(\eta, \tau)]+m \cdot[\theta(0, \tau)-$

$-\theta(\eta, \tau)-(\theta(1-\eta, \tau)-\theta(1, \tau))]\}$

де $m$ - параметр, який враховує чутливість коригувальних термобатарей та їх внесок у сумарний сигнал; $\eta=x / h-$ безрозмірна координата, $h-$ товщина сенсора.

На рис. 8 представлено результати математичного моделювання залежності виміряної відносної густини виміряного значення теплового потоку при ступеневій зміні вхідного потоку від критерію Фур'є $\left(F_{O}=a \tau / h^{2}\right.$, де $a-$ температуропровідність сенсора) 3 використанням рівняння (6), для випадку $\eta=0,5$ при варіації значень параметра $m(m=0,5 ; 0,56 ; 0,62 ; 0,705)$.

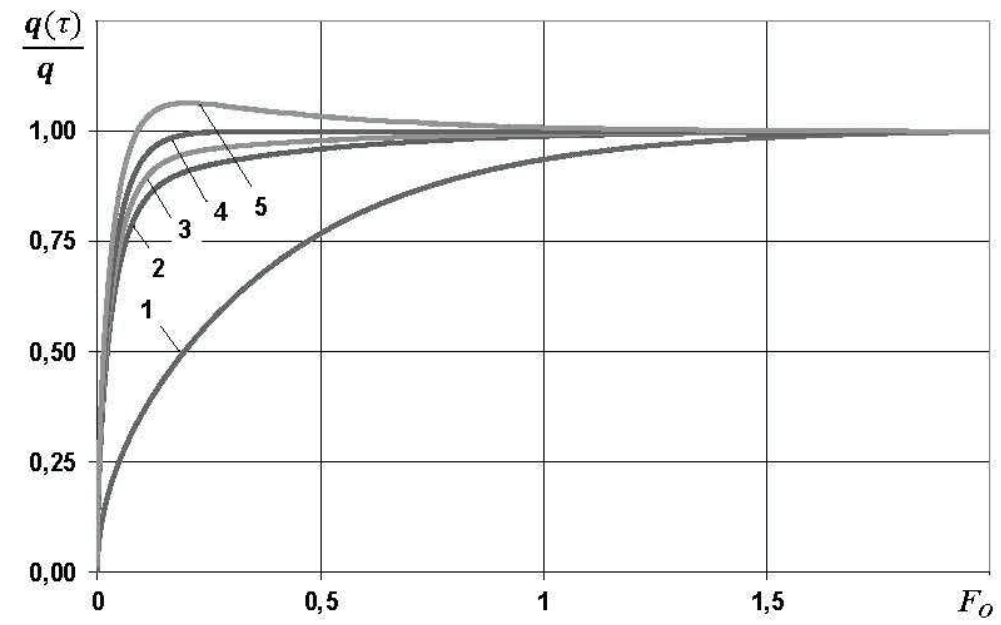

Рис. 8. Залежність відносної виміряної густини теплового потоку при $\eta=0,5$ від критерію Фур'є при варіації параметра т:

1 - ПТП без корегувальної термобатареї, тобто $n=2$, при $m=0$;

2 -двочаровий ПТП, тобто $n=3, m=0,5 ; 3-m=0,56 ; 4-m=0,62 ; 5-m=0,705$.

3 аналізу представлених на рис. 8 графіків випливає, що за наявності тільки трьох перетинів (для випадку $\eta=0,5$ ), між якими вимірюється різниця температури, при підборі числа $m$, можна досягти зниження інерційності сенсора, що не поступається результатам, отриманим для випадків $n=4 ; 5$ і більше.

Розглянуто різні випадки вимірювання теплового потоку при несталому режимі об'єкта контролю, а також контролю теплового потоку 
на обладнанні з тепловиділенням приладами для експрес-вимірювань, і показано, що застосування сенсорів з корегувальною термобатареєю завжди дає переваги за точністю вимірювання та швидкодією у порівнянні зі стандартними сенсорами теплового потоку.

Найчастіше сенсор теплового потоку 3 коригувальною термобатареєю виконують 3 двох термобатарей, одна 3 яких - основна, на теплосприймальну поверхню якої надходить тепло- вий потік, друга - корегувальна, гарячі спаї якої розміщено поблизу перерізу холодних спаїв основної термобатареї, та яка включена з основною диференційно. Можливі схеми побудови таких сенсорів показані на рис. 9.

Результати дослідження підтвердили, що створені перетворювачі мають постійну часу приблизно у 10 разів меншу ніж у традиційних сенсорів теплового потоку такої ж товщини.

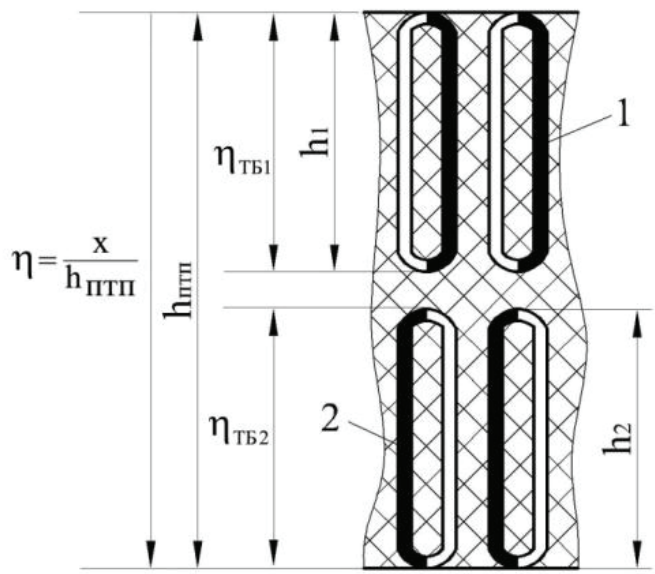

a

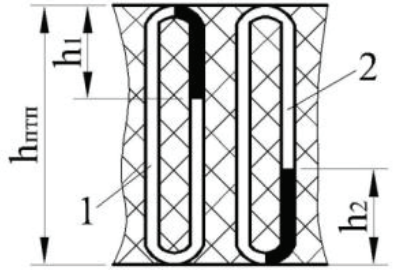

6

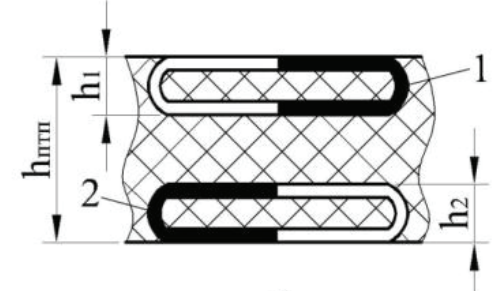

B

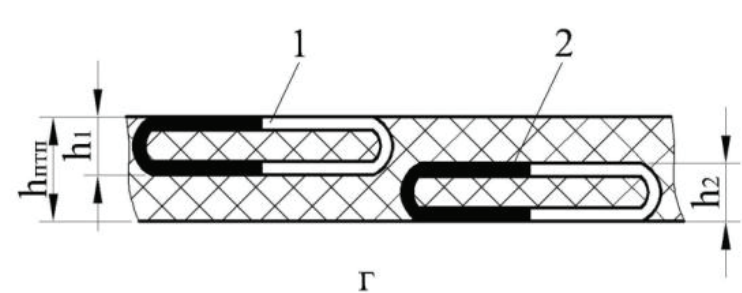

Рис. 9. Можливі схеми побудови малоінерційного сенсору теплового потоку: 1 -основна термобатарея, 2 -коригувальна термобатарея.

\section{Висновки}

Створено нові моделі сенсорів теплового потоку для систем моніторингу та діагностики енергетичного обладнання і при цьому:

- розроблено теорію проектування сенсорів зі зменшеним тепловим опором, що дозволило реалізувати вимірювання густини теплового потоку в умовах високоінтенсивного теплообміну;

- запропоновано і досліджено пари термоелектродних матеріалів константан-нікель і копель-нікель для застосування в термоелектрич- них сенсорах, що дозволило розширити діапазон вимірювання й збільшити часову стабільність характеристик сенсорів;

- запропоновано і розроблено способи покращення метрологічних характеристик сенсорів із застосуванням нікелевого покриття основного термоелектроду, що дозволило розширити температурний діапазон роботи сенсорів на область вище точки Кюрі для нікелю;

- запропоновано і теоретично обгрунтовано структуру поліметалічних сенсорів, виготовлених 3 термоелектричних матеріалів, які не 
піддаються технологічній операції волочіння, що дозволило підвищити чутливість сенсорів;

- розвинено теорію проектування сенсорів спеціального призначення, що дозволило вирішити завдання теплометрії неусталених процесів теплообміну.

\section{ЛІТЕРАТУРА}

1. Грищенко Т., Декуша Л., Шмаров С., Воробйов Л. Ефективний тепловий опір перетворювача теплового потоку виду допоміжної стінки // Метрологія та прилади : Науково-виробничий журнал. - Харків, 2012. - № 6. - С. 20-26. - ISSN 2307-2180.

2. Грищенко Т. Декуша Л., Шмаров С., Воробйов Л. Преобразователи теплового потока с тепловыми шунтами и температуровыравнивающими покрытиями // Промышленная теплотехника: Международный научно-прикладной журнал. Киев, 2013. - Т. 35, № 3. - С. 94-102. - ISSN 0204-3602.

3. Геращзенко O.A. Основы теплометрии. - К.: Наукова думка, 1971. - 192 с.

4. Декуша Л.В. Теплометрические измерительные преобразователи для исследования сложного теплообмена : дис. ... канд. техн. наук : 05.11.04 / Декуша Леонид Васильевич; Академия наук УССР, Институт технической теплофизики.- К., 1990. - 278 с.

5. Енергозбереження. Перетворювачі теплового потоку термоелектричні загального призначення. Загальні технічні умови : ДСТУ 3756-98. - [Чинний від 2000-07-01]. - К. : Держспоживстандарт України, 2000. - 21 с. - (Національний стандарт України).

6. Шмаров Е.В., Декуша Л.В., Воробьев Л.И., Грищзенко Т.Г. Биспиральный преобразователь теплового потока // Промышленная теплотехника: Международный научно-прикладной журнал. Киев, 2012. - Т. 34, № 6 - С. 86-93. - ISSN 02043602 .

7. Патент 102475 UA, МПК G01K 17/08 Перетворювач теплового потоку / Декуша Л.В., Шмаров Є.В., Грищенко Т.Г., Воробйов Л.Й.; заявник Інститут технічної теплофізики НАН України. - Опубл 10.07.2013. - Бюл. № 13. - 2013.
8. Декуша Л.В., Грищзенко Т.Г., Воробъев Л.И. Многослойные гальванические преобразователи теплового потока // Міжвідомчий наук.-техн. збірник : Вимірювальна техніка та метрологія. Вип. 64. - Львів : «Львівська політехніка», 2003.C. 48-52. - ISSN - 0368-6418.

9. Декуша Л.В., Грищзенко Т.Г., Воробьев Л.И. Специализированные преобразователи теплового потока // Промышленная теплотехника: Международный научно-прикладной журнал. - Киев, 2003. - Том 25, Приложение к журналу № 4. C. 464-466. - ISSN 0204-3602.

10. Декуша Л.В., Грищенко Т.Г., Воробьев Л.И. $\left[\begin{array}{ll}u & \partial p .]\end{array}\right]$ Особенности проектирования преобразователей теплового потока для исследования нестационарного теплообмена // Промышленная теплотехника: Международный научно-прикладной журнал. - Киев, 2008. - Т. 30, № 2. C. 99-104. - ISSN 0204-3602.

11. Декуша Л., Воробьев Л., Грищзенко Т., Декуша О., Пархоменко Г. Особенности проектирования малоинерционных ПТП для исследования нестационарного теплообмена. // Вимірювальна техніка та метрологія: міжвідомчий науковотехнічний збірник; за ред. Б.І. Стадника. - Львів: Видавництво Національного універси-тету «Львівська політехніка», 2008. - Вип. 68 C. 116-125. - ISSN 0368-6418.

12. A.c. 875222 (СССР), МКИЗ G 01 К 17/0. Датчик теплового потока / Л. В. Декуша, А. Г. Мазуренко, В. Г. Федоров [и др.]. - № 2878032/18-10; заявл. 19.02.80; опубл. 23.10.81, Бюл. № 39 (53). $-7 \mathrm{c}$.

13. Декуша Л.В., Воробьев Л.И., Декуша О.Л., Грищенко Т.Г. Преобразователь теплового потока с корректирующей термобатарей // Метрологія та вимірювальна техніка (МЕТРОЛОГІЯ-2008): матеріали VI Міжнародної науково-технічної конф.- Харків, 2008. - С. 333- 339.

14. Воробьёв Л., Грищченко Т., Декуша Л., Декуша О., Ковтун С., Шмаров Е. Теплометрические средства контроля тепловой нагрузки на головной обтекатель ракеты-носителя // Метрологія та прилади: Науково-виробничий журнал. - Харків, 2013. - № 2. - C. 22-29. - ISSN 2307-2180. 


\section{NEW MODELS OF HEAT FLOW SENSORS FOR MONITORING AND DIAGNOSTIC SYSTEMS OF POWER EQUIPMENT}

\section{Vorobiov L., Dekusha L., Kovtun S.}

Institute of Engineering Thermophysics NAS of Ukraine,

vul. Zhelyabova, 2a, Kiev, 03680, Ukraine

Objective. Creation of new models of heat flux sensors for monitoring and diagnostics systems of power equipment.

Results. New models of heat flux sensors for monitoring and diagnostics power equipment are designed, including:

- The theory of sensor design with a reduced thermal resistance is developed, that allowing re-alize measurement of heat flux at high-intensity heat exchange;

- Thermocouple materials nickel-constantan and copel-nickel for use in thermoelectric sensors are proposed and studied, that allowing to expand the range of heat flux measurement and to increase characteristics stability on operation time of the sensor;

- Ways to improve metrological characteristics of sensors using nickel plating of main thermoelectrodes are proposed and developed, that allowing to extend the temperature range of sensor's use to region above of the Curie point for nickel;

- Structure of polymetallic sensors, made of thermoelectric materials that cannot be dragging, is proposed and theoretically grounded, thus improving the sensitivity of the sensor;

- The theory of special purpose sensor design is developed, that allowing solving the problem of heat flux measurements at unsteady heat exchange.

References 14, figures 9.

Key words: heat flux sensor, monitoring systems, thermal power equipment.

1. Grishenko, T., Dekusha, L., Shmarov, I., \& Vorobyov, L. (2012). Effective thermal resistance of heat flow tranducer auxiliary wall type. Metrology and Instruments, No 6 (ISSN 2307-2180), P. 20-26. (Rus.)

2. Grishenko, T., Dekusha, L., Shmarov, I., \& Vorobyov, L. (2013). Transducers of heat flow with thermal noise and temperature leveling coatings.
Industrial Heat Engineering, Vol.29 №2 (ISSN 02043602), P. 94-102. (Rus.)

3. Geraschenko O. (1971). Heatmetry. Kyiv: Naukova dumka.192 p. (Rus.)

4. Dekusha, L. Heatmetry measuring transducers for study of complex heat exchange: thesis submitted to the degree of Candidate in technical sciences : 05.11.04 / Institute of Technical Thermophysic of the National Academy of Sciences of Ukraine.- K., 1990. - 278 p. (Rus.)

5. Energy-saving. Thermoelectric transformers of heat flow for general purpose. General specifications: ДСТУ 3756-98. - [Valid from 200007-01]. Derghspoghivstandart, 2000. - 54p.

6. Shmarov, I., Dekusha, L., Vorobyov, L. \& Grishenko, T. (2012). Bicoiled heat flux transducer. Industrial Heat Engineering, Vol.34, №6 (ISSN 0204-3602), P. 86-93. (Rus.)

7. Patent 102475 UA, МПК G01K 17/08 Heat flux transducer. Dekusha, L., Shmarov, I., Vorobyov, L., \& Grishenko, T. ; patentee is Institute of Engineering Thermophysics National Academy of Sciences of Ukraine. - Publ. 10.07.2013. - Bull. No 13. -2013.

8. Dekusha, L., Vorobyov, L. \& Grishenko, T. (2003). Multi-layer galvanic heat flux transducers // Metrology and Measuring Equipment. Vol.64 (ISSN 0368-6418), P. 48-52. (Rus.)

9. Dekusha, L., Vorobyov, L. \& Grishenko, T. (2003). Specialised heat flux transducers. Industrial Heat Engineering, Vol.25, №4 (ISSN 0204-3602), P. 464-466. (Rus.)

10. Dekusha, L., Grishenko, T., Vorobyov, L. \& other (2008). Features of heat flux transducer design for the study of unsteady heat exchange. Industrial Heat Engineering, Vol.30, №2 (ISSN 0204-3602), P. 99-104. (Rus.)

11. Dekusha, L., Vorobyov, L., Grishenko, T., \& other (2008). Features of heat flux transducer design for the study of unsteady heat exchange. Metrology and Measuring Equipment. Vol.68 (ISSN 03686418), P. 116-125. (Rus.)

12. Inventor's certificate No 875222 (USSR), МКИЗ G 01 К 17/0. Heat flux sensor / Dekusha, L., Mazurenko, A., Phyodorov, W., \& other. No 2878032/18-10 ; Publ. 23.10.1981. - Bull. No 39(53).

13. Dekusha, L., Vorobyov, L., Dekusha, O., 
Grishenko, T., (2008). Heat flux transducer with correction thermopile. «Metrology and Measurement Techniques» («Metrology - 2008») : collected papers of VI International Scientific and Technical Conference, Kharkiv, P. 333-339. (Rus.)
14. Vorobyov, L., Grishenko, T., Dekusha, L., \& other (2013). Heat flux transducers for control of heat load on the aerodynamic paylod fairing of a lounch-vehicle. Metrology and Instruments, No 2 (ISSN 2307-2180), P. 22-29. (Rus.)

Получено 08.08.2016

Received 08.08.2016 